\title{
Impact of ablation dose in the treatment of thyroid cancer with 1-131
}

\author{
Cholid Badri, Dharma Gayo, Suryo Seto
}

\begin{abstract}
Abstrak
Tujuan : Untuk menilai keberhasilan terapi ablasi dengan lodium-131 menggunakan dosis yang berbeda pada penderita karsinoma tiroid berdiferensiasi baikyang telah menjalani operasi tiroidektomi total atau hampir total.

Cara : Penelitian retrospektif terhadap 42 pasien yang dirawat di Rumah Sakit Dr Cipto Mangunkusumo antara tahun 1993 - 1996. Diberikan ablasi dengan dosis $80 \mathrm{mCi}$ dan $\mathrm{JOO}$ mCi pada kelompok pasien yang masing-masing terdiri dari 21 penderita. Sebelum ablasi, dilakukan pemeriksaan dengan sidik tiroid dan seminggu sesudah ablasi dilakukan sidik seluruh tubuh. Penilaia11 keberhasila11 ablasi dilakukan 3 bulan setelah ablasi dengan pemeriksaan sidik seluruh tubuh dengan 5 mCi 1-131.

Hasil : Keberhasilan terapi ablasi denga11 dosis $100 \mathrm{mCi}$ berbeda bermakna dengan dosis $80 \mathrm{mCi}$, yaitu sebesar 85,7\% dibandi11gkan dengan $57 \%(p=0,04)$. Efek samping akut dijumpai sebanyak $19 \%$ pada pemberian dosis $100 \mathrm{mCi}$ dan 4,8 \% pada dosis 80 mCi. Sidik tiroid yang dilakukan I minggu setelah ablasi menunjukkan metastasis sebanyak $19 \%$ denga11 pemberian dosis JOO 111Ci dan $4,8 \%$ dengan dosis $80 \mathrm{mCi}$.

Kesimpulan : Ablasi dengan dosis 100 mCi 1-131 memperlihatkan hasil yang lebih baik dibandingkan dosis 80 mCi dan tidak meningkatkan efeksamping pengobatan secara bermakna. Di samping ituablasi dengandosis JOO mCikemungkinan dapatlebihba11yak menemukan adanya metastasisjauh dibandingkan dengan dosis $80 \mathrm{mCi}$.
\end{abstract}

\begin{abstract}
Purpose : To evaluate the efficacy of ablation therapy using Iodine-] 31 with two different doses on patients with well-differentiated thyroid cancer who had been operated upon with total or near-total thyroidectomy.

Methods: A retrospective study was conducted on 42 patients admitted at the Dr. Cipto Mangunkusumo Hospital, Jakarta between 1993-1996. Thyroid ablation was performed with $80 \mathrm{mCi}$ and $100 \mathrm{mCi}$ on each group consisting of 21 patients respectively. Thyroid scan was performed before ablative procedure, and followed by whole body scanning one week after the ablation.. Efficacy of the treatment was evaluated three months after ablation therapy using whole body scanning with $5 \mathrm{mCi}$ of 1-131.

Results : The efficacy of ablation therapy with a dose of $100 \mathrm{mCi}$ was $85,7 \%$, significantly better than $57 . \%$ with a dose of $80 \mathrm{mCi}$ dose $(p=0,04)$. Acute side effects were seen in 4,8 \% with a dose of JOO mCi and $19 \%$ of patients with a dose $80 \mathrm{mCi}$. Whole body scanning peiformed one week after ablation therapy revealed 19\% distant metastases with the dose of $100 \mathrm{mCi}$ as compared to 4,8 \% with the dose of $80 \mathrm{mCi}$.

Conclusions : Thyroid ablation with a dose of $100 \mathrm{mCi}$ 1-131 showed a better result as compared to $80 \mathrm{mCi}$ dose, as side effects of the treatment were not significantly different. Moreover, ablation therapy with a dose of $100 \mathrm{mCi}$ probably could detect more distant metastases as compared to $80 \mathrm{mCi}$ dose.
\end{abstract}

Keywords : Thyroid cancer, radioiodine treatment, ablation dose

\section{INTRODUCTION}

Ablation with radioiodine (I-131) is to eliminate thyroid tissue remnants in thyroid cancer patients after surgical treatment. Some retrospective studies showed that treatment with radioiodine was the only best prognostic indicator on free of disease interval and improvement of survival rate of well differentiated thyroid cancer patients. ${ }^{1.2}$

Department of Radiology, Faculty of Medicine University of Indonesia, Dr. Cipto Mangunkusumo Hospital, Jakarta, Illdonesia
Surgery is the primary treatment of thyroid cancer, and all follicular and papillary carcinomas wi th a diameter of more than $\mathrm{L} \mathrm{cm} \mathrm{-} \mathrm{1,5} \mathrm{cm} \mathrm{are} \mathrm{suggested} \mathrm{to} \mathrm{undergo}$ total or near-total thyroidectomy due to mul ticentrici ty of Lhe Lumour. ${ }^{2}-4$

Such aggressive surgical approach cou ld enhance the ability of I-131 to ablate the remai ning gland and to treat distant metastases. Residual thyroid ti ssue wi ll prevent detection of local dan distant metastases on follow-up with I-13 I scanning. ${ }^{5}$

Incidence of thyroid cancer is low and the presentation too variable, thus until now no treatmen $\mathrm{t}$ protocols 
have been evaluated in randomized control manner for efficacy of therapy. ${ }^{6} \cdot{ }^{7}$ Nevertheless, there are two different opinions on the dosage that should be given for thyroid cancer ablation. It is known that the low dose ranges from $30-50 \mathrm{mCi}$ and the high dose from 80 - $150 \mathrm{mCi}$ of $1-131$.

Since 1990, at the Dr. Cipto Mangunkusumo Hospital, a dose of $80 \mathrm{mCi}$ has been used for ablation and the success rate achieved was 58\% for the group of papillary type, and $70 \%$ for the follicular type. But, with a re-irradiation, a higher success rate could be achieved as high as $67 \%$ and $80 \%$ respecti vely. Therefore, it was estimated that a dose higher than $80 \mathrm{mCi}$ would be needed to achieve better ablation result. According to Beierwaltes, IO the effective ablation dose is between 100 - $150 \mathrm{mCi}$ despite reports from other authors showing that a lower dose was also effective as well. ${ }^{11}$ Based on these references, since 1993 some of the patients were irradiated with a dose of $100 \mathrm{mCi}$ for ablation instead of $80 \mathrm{mCi}$.

The aim of this study is to compare the efficacy of the treatment using both different doses and its toxicity as well.

\section{METHODS}

Data were collected - from medical records of all patients who underwent ablation during 1991 to 1996 at the Radiotherapy Unit, Dr. Cipto Mangunkusumo Hospital. The diagnosis of thyroid cancer was routine$\mathrm{l} \mathrm{y}$ confirmed and classified according to the WHO classification at the Departmen $t$ of Anatomic Pathology, Facul ty of Medicine University oflndonesia. The follicu 1 ar variant of papillary thyroid cancer was categorized into the papillary type, while the Hiirthle type was put into the follicular one.

Patients who came to the Radiotherapy Unit generally had been operated upon previously at the Department of Surgery of the same institution or from other hospitals. The determination of clinical staging was based on physical examination, surgi cal report, histopathologic examination and on the possibility of metastatic spread to regional lymph nodes or distant metastases. The TNM system was used and based on the UICC classification of $1987 .^{9}$

The subjects were all patients who fulfilled the inclusion criteria, consisting of a well differentiated thyroid cancer (follicular or papillary), resid ual thyroid tissue detected on postoperative thyroid scanning, had been on a low iodine diet for more than 1 week and had undergone total or near-total thyroidectomy. The ex- clusion criteria were thyroid cancer of other type than follicular or papillary type, poor general condition and blood hemoglobin less than $10 \mathrm{~g} \%$.

Post-operative thyroid scanning was performed with $1 \mathrm{mCi} 1-131$, mostly wi thin 4 to 6 weeks after thyroidectomy. The administration of substitute hormone after surgery, if any, should be withheld 2 weeks before the scanning. If resid ual thyroid tissue was still found on the scanning, the preparation for the ablative procedure was started. Patients were subsequently put on a low iodine diet and withheld from the substitute hormone for about 2 weeks. At the end of the preparation, laboratory tests were performed inclu din g amon g others: T3, T4, TSH , seru $\mathrm{m}$ thyroglobuli n, hemoglobin, leucocytes, and thrombocytes.

The ablation should be performed soon after the preparation was completed. During the administration of $1-131$, the patients were put into an isolation room. The patients were asked to drink much water and urinate frequently as a method to lower radiation dose to whole body and particularly to the bladder. Urine and faeces were collected and treated as a special waste. Acute side effects, if occurred, were treated symptomatically as needed.

Body uptake was measu red using a survey meter, at 1 hour after administration of 1-131, and repeated 48-72 hours afterwards. Patients were allowed to leave the hospital when measurement from 3 meter distance gave a finding of less than $0,37 \mathrm{mR} /$ hour.

Post-ablative whole body scanning was performed 1 2 weeks after the ablation to find out the possibility of existing distant metastases. Af ter whole body scanning, thyroid hormone was continuously given to the patients as a suppressive therapy.

Clinical follow-up was done regularly after 1 week, 1 month, 3 months, 6 mon ths, 1 year, and every 2 years after the ablation. Follow-up wi th whole body scanning was performed using a dose of $5 \mathrm{mCi} 1-131$, at 3 months after ablation.

Ablation was taken as successful if the whole body scanning did not reveal any residual thyroid tissue. If no residual thyroid tissue nor metastases was found on scanning, administration of suppressi ve therapy was continued. If residual thyroid tissue was noted, ablation was immediately repeated with the same procedure as before. Whole body scanning was repeated after 6 months, 1 year, and subsequently every 2 years $<$ Fi1rnre 1). 
Total thyrodectomy

$$
\text { ) -3-4 weeks }
$$

Thyroid scanning $1 \mathrm{mCi}$

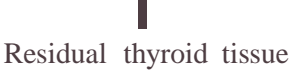

$\mid \begin{gathered}\text { low iodine diet } \\ \text {-- } 3 \text {, T4, TSH, Hb, WBC } \\ \text { thrombocyte }\end{gathered}$

I-131 therapy

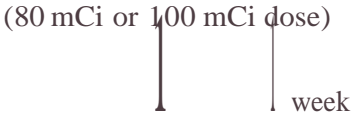

Whole body scanping

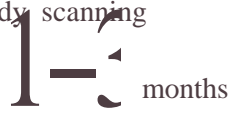

lebody

TIIIIII

Metastases +

Residual tissue

1

$100 / 150 \mathrm{mCi}$

$80 / 100 \mathrm{mCi}$

Metastases

Follow-up

Figure 1. Management of therapy for thyroid cancer with 1-131 al Radiotherapy Unit Dr. Cipto Mangu11kusumo Hospital

\section{RESULTS}

\section{Patient Characteristics}

Among 42 patients, the most freq uent histopathologic finding was the papillary type, found in 27 patients (64,3\%). Most patients (15 out of 42 patien ts, $36 \%$ ) were in the age group of 21-30 year. Out of all patients studied, the most frequent were female, i.e. 27 patients $(64,3 \%)$ and in this female group, the histopathologic findings were nearly equal, 14 of papillary and 13 of follicular type. There were 15 male patients and 13 ( 86,6 \%) of them had a histology of papillary type $(p=0,002)$. Thus in this study the papillary type was significantly more frequent than the folliculary type in the male patients.

The distribution of age, sex and histopathologic types are presen ted in Tables $1 \& 2$.
Table 1. Distribution of age and histopathologic types

\begin{tabular}{cccc}
\hline \multirow{2}{*}{ Age } & \multicolumn{2}{c}{ Histopathologic types } & \\
\cline { 2 - 3 } Year & Papillary & Follicular & Total \\
\hline $21-30$ & 8 & 7 & 15 \\
$31-40$ & 3 & $\mathbf{I}$ & 4 \\
$41-50$ & 9 & 3 & 12 \\
$51-60$ & 3 & 3 & 6 \\
$>60$ & 4 & 1 & 5 \\
Total & & & \\
\hline
\end{tabular}

Table 2. Distribution of sex and histopathologic types

\begin{tabular}{lccc}
\hline \multirow{2}{*}{ Sex } & \multicolumn{2}{c}{ Histopathologic } & \\
\cline { 2 - 4 } & Papillary & Follicular & Total \\
Male & 13 & & \\
Female & 14 & 13 & 15 \\
Total & 27 & 15 & 27 \\
\hline
\end{tabular}

\section{The Extent of Tumor}

Among 42 patients with a well differenti ated thyroi d cancer included in this study, the highest number of cases were in Stage I, 24 patien ts (57\%). The othe rs were included in stage II, 5 patien ts $(12 \%)$ and stage III, 7 patients (17\%). Six patients (14\%) were classified into stage IV according to metastatic lesions detected on whole body scann ing after abl ation. The relationshi p between stages and histologic finding as well as relationshi p between age grou ps and stages are presented in Table 2 and Table 3.

Table 3. Relationship between stage and histopathologic types

\begin{tabular}{cccc}
\hline \multirow{2}{*}{ Stage of Tumor } & \multicolumn{2}{c}{ Histopathologic types } & \multirow{2}{*}{ Total } \\
\cline { 2 - 3 } & Papillary & Follicular & \\
\hline & 14 & I O & 24 \\
II & 3 & 2 & 5 \\
III & 5 & 2 & 7 \\
IV & 5 & & 6 * \\
\hline Total & 27 & 15 & \\
\hline
\end{tabular}

* Stage IV was confirmed after ablation 


\section{Surgery}

The highest number of surgery performed was total thyroidectomy, with or without dissection of neck lymph nodes (95\%). In this study, 1 patient underwent right isthmolobectomy. Since this patient refused to undergo a second surgery, an external radiation was added to the neck with a dose of $50 \mathrm{~Gy}$. However, even after the external radiation the thyroid scanning still showed uptake of I-131. Relationship between types of surgery with doses of ablation is presented in Table 5.

Table 4. Relationship between Age group and Stage

\begin{tabular}{crrrrr}
\hline Age (in years) & \multicolumn{3}{c}{ Stage } & & Total \\
\hline & & II & III & IV & \\
$21-30$ & 13 & 2 & & & 15 \\
$31-40$ & 4 & & & & 4 \\
$41-50$ & 7 & & 3 & 1 & 12 \\
$51-60$ & & & 3 & 2 & 6 \\
$>60$ & & & & 3 & 5 \\
\hline Total & 24 & 5 & 7 & 6 & 42 \\
\hline
\end{tabular}

Table 5. Relationship between types of surgery and dose of ablation

\begin{tabular}{lrrr}
\hline \multirow{2}{*}{ Types of Surgery } & \multicolumn{3}{c}{ Dose of ablation } \\
\cline { 2 - 4 } & $80 \mathrm{mCi}$ & $100 \mathrm{mCi}$ & Total \\
\hline Total thyroidectomy & 7 & 6 & 13 \\
- With lymph glands dissection & 13 & 14 & 27 \\
- Without lymph glands dissection & & 1 & $\mathbf{1}$ \\
$\begin{array}{l}\text { Near-total thyroidectomy } \\
\text { lsthmolobectomy }\end{array}$ & & & $\mathbf{1}$ \\
\hline Total & 21 & 21 & 42 \\
\hline
\end{tabular}

\section{Result of Ablation}

The correlation among sex, age, stage, type of surgery, h i stopat hologic findi ng, dose of medication, and fail ure of ablation was analyzed statistically with chisquare test and Fischer test.

Evaluation of results achieved in the first three months were as follows :

success rate based on dose administered for 100 $\mathrm{mCi}$ and $80 \mathrm{mCi}$ groups were $86 \%$ and $57 \%$ respectively $(\mathrm{p}<0.04)$. success of ablation achieved was $80 \%$ in males and $67 \%$ in females ( $p>0,05)$;

for age less than 45 years, success achieved was $79 \%$, and for the age group of 45 years and older was $57 \%(p>0,05)$.

based on histopathologic findings, success achieved for papillary type was $77 \%$, and $63 \%$ for follicular type $(p>0,05)$;

success rate for Stage I was $75 \%$ as for Stage II-IV was $67 \%(p>0,05)$.

\section{Side Effects}

Ablation wi th the dose of $80 \mathrm{mCi}$ produced acute side effects in 4 out of 21 patients (19\%) in the form of nausea in 1 patient, dysphagia in 1 patient and hoarseness in 2 patients. Ablation with the dose of $100 \mathrm{mCi}$ produced acute side effects only in 1 out of 21 patients $(4,8 \%)$ in the form of neck edema. These complaints were taken care off with symptomatic therapy. Corticosteroid therapy was given for neck edema, and the patient recovered within a few days.

\section{DISCUSSION}

In this study, the factor of the dose amount resul ted in significant difference of ablation results. A dose of $100 \mathrm{mCi}$ gave a success rate of $86 \%$, while a dose of $80 \mathrm{mCi}$ gave only $57 \%$. Several results of previous studies showed that a high initial dose of 1-131 will improve the success rate of ablation and lessened the need for a repeat ablation. -

Beierwaltes ${ }^{13}$ suggested that residual tissue which still took 1-131 in the thyroid bed should be given a dose of ablation no less than I00 mCi. As an adjuvant therapy, a close of $100-150 \mathrm{mCi}$ should be given to ablate micrometastases unseen in I-131 scanning wi th 1-5 $\mathrm{mCi}$, particularly if prior to ablation tumor uptake was known to be quite low $(<4 \%) .{ }^{10},{ }^{14}$

At our institution, the ablation procedure has been applied since 1987 in several patients with a dose of 30 $\mathrm{mCi}$. This low dose was chosen to make it possible for the patient to get ambulatory treatment since the waste treatment facility was poor. One year later, with a better waste treatment facility, the dose was increased to $50 \mathrm{mCi}$. In 1990, a general concensus with other departments an $\mathrm{d}$ con sider ing $\mathrm{m}$ any referen ces produced a protocol for ablation with a dose of 80 mCi. 
On evaluation of patients treated from 1990-1992, 8 using the dose of $80 \mathrm{mCi}$, the average success rate of ablation performed on 44 patients was $64 \%$, wi th a higher success rate on follicular type (70\%) compared with papillary type $(58 \%)$. Patients who were not ablated at the first treatment, most of them will be ablated on subseq uent treatment, therefore the success rate for ablation could be improved from $64 \%$ to $79,5 \%$. This fact lead to an assumption that the dose given on the first ablation was relati vely less than optimal, and this was also in accordance with Beierwaltes' opinion who suggested $100-150 \mathrm{mCi}$ as the dose for ablation. ${ }^{10}$

The present study showed that administration of 100 $\mathrm{mCi}$ ablation dose resul ted in a significant better success rate than $80 \mathrm{mCi}$, that was $85,7 \%$ as compared to $57 \%(p=0,04)$. These findings were found to have no significant correlation between success rate of ablation with those vari ables such as age, sex, type, stage and histopathologic type.

Therefore, radiation with a dose of $100 \mathrm{mCi}$ was better than $80 \mathrm{mCi}$ because the success rate was higher, and there was no need for the patient to undergo a second ablation. It can reduce days of hospitalization, shorten the hypothyroid period in ablation preparation, and may also lessen the occurrence of metastases before a second ablation was performed.

Ablation with $80 \mathrm{mCi}$ dose caused side effects in 4 out 21 patien ts (19\%), those were nausea in I patient, dysphagia in 1 patient, and hoarseness in 2 patients. With $100 \mathrm{mCi}$ dose, side effects occurred in the form of neck edema in I patient $(4,8 \%)$. Nausea was an early side effect of 1-131 therapy and lasted from 1 hour to 2 days, and responded well to anti-emetic administration. Pain, unease feeling and disturbance of salivary gland production were early complications which could be handled well.

Hoarseness was caused by a temporary edema of the salivary glands which resulted in pressure to the recurrent nerve. The characteristic of neck edema was seen as a painful swollen neck, which occurred 48 hours after therapy, and was related to invasion of tumor to the soft tissues or due to too much thyroid remnant left. ${ }^{1}$

Using a dose of $100 \mathrm{mCi}$ in this study did not increase quantitati vely side effects compared to a dose of 80 mCi. Qualitatively, the side effects found in the group given a $100 \mathrm{mCi}$ dose was a little more grave, such as edema of the neck, but this side effect could be managed with administration of corticosteroi ds.

As the ablation dose of $80 \mathrm{mCi}$ used in this study showed $4,8 \%$ metastases $(1 / 21)$ in the bones, the 100 mCi dose revealed $19 \%$ of metastases (4/21) including 3 metastases in the bones and 1 in the lymph node. The number of patient wi th metastases was higher in the ablation dose of $100 \mathrm{mCi}$ as compared to the dose of 80 mCi (19 \% vs 4,8\%). The probable cause could be the fact that metastatic deposi ts of carcinoma took Jess $1-131$, thus a higher dose is needed to reveal the acti vi ty on whole body scanni ng. Nevertheless, the possibility remained that those patients who were given a dose of $100 \mathrm{mCi}$ had in fact distant metastases in a greater number compared to the group wh ich was given a $80 \mathrm{mCi}$ dose.

There are several limitations found in this study, such as no records were avail able about the size of the tumor, multicentricity, estimation of residual thyroid gland, TSH blood level before ablation, and resul ts of follow-up on ablation for the first three months after ablation. Those variables shou ld be considered in further studies of the ablation dose.

\section{REFERENCES}

1. Varma VM, Beierwaltes WH, Nofal MM, Nishiyama RH, Copp JE. Treatment of thyroi d cancer: Death rate after surgery and after surgery followed by sodium iodine 1-131. JAMA, 1970; 214: 1437-42.

2. Mazzaferri EL, J hi ang SM. Long term impact of ini tial surgical and medical therapy on papillary and follicular thyroid cancer. Am J Med 1994; 97: 418-23.

3. Ramli HM, Kamajaya. Penatalaksana an karsi noma tiroid di Bagian Bedah Sub Bagian Bedah Onkologi FK U l/RSCM. Dalam: Keganasan ku lit leher dan kepala. Semarang: Badan Penerbit Univ. Diponegoro, 1991; 185-200.

4. Wanebo HJ, Andrews W, Kaiser DL. Thyroid cancer: some basic considerations. Am 1 Surg 1981; 142: 474-9.

5. Sweeney DC, Johnston GS. Radioiodi ne therapy for thyroid cancer. Endocrinol Metab Clin North Am 1995; 72: 828-32.

6. Maxon III HR, Smi th HS. Radioiodi ne-131 in the diagnosis and treatment of metastatic well differentiated thyroid cancer. Endocrinol Metab Clin North Am 1990; 19: 685-71 8

7. Robbins J. Thyroid cancer: A lethal endocri ne neopl asm. Ann Intern Med 199J ; 115:133-9.

8. Badri C, K uswanto O, Gond howi a rdjo S, Astarto B, Kusumawidjaya H. Papillary and follicular thyroi d cancer: Impact of treatment in 44 patien ts at the Cipto $\mathrm{M}$ angunkusu mo Hospital. Med J Univ Indon 1994; 4 : 42-7.

9. Hermanek P, Sobin LH. TNM classification of malignant tumors. International Union Against Cancer. $4^{1} \mathrm{~h}$ ed. New York : 1987. 
IO. Beierwaltes WH, Rabbani R, Dmuchowski C, Lloyd RV, Eyre P, Mallette S. An analysis of ablation of thyroid remnants with I-131 in 511 ptients from 1947-1984: Experience at the University of Michigan. J Nucl Med 1984; 25:1287-93.

11. DeGroot LJ, Reilly M. Comparison of 30 and $50 \mathrm{mCi}$ dose of Iodine-131 for thyroid ablation. Ann Intern Med 1982; 96:51-53.
12. Mazzaferri EL, Young RL. Papillary thyroid cancer: A IO year follow-up report of the impact of therapy in 576 patients. Am J Med 1981; 70:511-8.

13. Beierwaltes WH. The treatment of thyroid cancer with radioactive iodine. Semin Nucl Med 1978; 8: 79-93.

14. N, Triaspolitica. "Mengenal Penyakit Kanker, Jenis, Gejala, Penyebab Berikut Pengobatan Kanker." Mau Nanya Dong Dok. N.p, 20 June 2017. Web. 28 June 2017. $<$ https://nanyadongdok.blogspot.com/2017/06/mengenalpenyakit-kangker-jenis-gejala.html $>$. 